\title{
Climatic Changes and Anthropogenic Activities Driving the Increase in Nitrogen: Evidence from the South-to-North Water Diversion Project
}

\author{
Yuanzhu Wang ${ }^{1,2}$, Yuan Li ${ }^{1,3}$, Jiankui Liang ${ }^{4}$, Yonghong Bi ${ }^{1, *}$, Shulei Wang ${ }^{4}$ and Yuming Shang 4 \\ 1 State Key Laboratory of Freshwater Ecology and Biotechnology, Institute of Hydrobiology, \\ Chinese Academy of Sciences, Wuhan 430072, China; wangyuanzhu111@sina.com (Y.W.); \\ liyuan_198711@sina.com (Y.L.) \\ 2 University of Chinese Academy of Sciences, Beijing 100049, China \\ 3 School of Environment and Safety, Taiyuan University of Science and Technology, Taiyuan 030024, China \\ 4 Management Bureau of South to North Water Transfer Canal Project, Beijing 100038, China; \\ liangjiankui@126.com (J.L.); wangshulei@nsbd.cn (S.W.); shangym952324@163.com (Y.S.) \\ * Correspondence: biyh@ihb.ac.cn; Tel.: +86-27-687-80016
}

Citation: Wang, Y.; Li, Y.; Liang, J.; Bi, Y.; Wang, S.; Shang, Y. Climatic

Changes and Anthropogenic

Activities Driving the Increase in Nitrogen: Evidence from the South-to-North Water Diversion Project. Water 2021, 13, 2517. https:// doi.org/10.3390/w13182517

Academic Editor: Stefano Cozzi

Received: 2 July 2021

Accepted: 9 September 2021

Published: 14 September 2021

Publisher's Note: MDPI stays neutral with regard to jurisdictional claims in published maps and institutional affiliations.

Copyright: (c) 2021 by the authors. Licensee MDPI, Basel, Switzerland. This article is an open access article distributed under the terms and conditions of the Creative Commons Attribution (CC BY) license (https:// creativecommons.org/licenses/by/ $4.0 /)$.

\begin{abstract}
As one of the most widespread elements, nitrogen has been broadly concerned in water bodies. Understanding variations in nitrogen is of paramount importance to ecosystem stability and human health. The spatiotemporal variations in total nitrogen (TN) and ammonia in the Middle Route of the South-to-North Water Diversion Project (MRP) during the period from 2015 to 2019 were evaluated. The correlation between anthropogenic activities based on quantitative land use cover and nitrogen concentration was addressed. The results indicated that TN increased by $0.072 \mathrm{mg} / \mathrm{L}$ from south to north over the period $(p<0.05)$, but ammonia decreased by $0.018 \mathrm{mg} / \mathrm{L}(p<0.05)$, notably, in five years. In addition, $\mathrm{Chl} a$ had the highest concentration in autumn, showing seasonal variation. The linear regression showed that ammonia concentration was significantly negatively correlated with Chl $a(p<0.1)$. Furthermore, as human activities' intensity increased by 6\% from 2015 to 2019, $\mathrm{TN}$ increased and ammonia decreased. The rhythm of meteorological conditions could also result in the variation in nitrogen, which affected $\mathrm{N}$ concentration in the MRP. The increase in construction land and agricultural land led to TN increase, and algae absorption was one of the reasons leading to the decrease in ammonia. It could be concluded that climatic changes and anthropogenic activities were the driving forces of nitrogen changes in the MRP. Thus, land use changes around the MRP should be the focus of attention to reduce the nitrogen concentration. This study is the first report on the nitrogen distribution pattern in the MRP. It could be useful to authorities for the control and management of nitrogen pollution and better protection of water quality.
\end{abstract}

Keywords: total nitrogen; ammonia; land use cover; anthropogenic activities intensity; algal absorption; Middle Route of South-to-North Water Diversion Project

\section{Introduction}

Nitrogen is an important component of ecosystems [1,2]. The nitrogen cycle is one of the basic material recycling in the environment [3], which is related to assimilation, ammonification, nitrification, denitrification, anaerobic ammonium oxidation (anammox), and nitrogen fixation [4]. Excessive nitrogen can cause adverse effects on the environment, including soil acidification [5], loss of oxygen, and subsequent fish death [6]. A high concentration of nitrogen is the main element responsible for eutrophication in the aquatic environment $[7,8]$, which leads to a reduction in biodiversity and deterioration of water quality [9]. Furthermore, high contents of nitrogen exist in drinking water, posing a threat to human health [10]. For example, excessive nitrite in drinking water could lead to a condition known as "methemoglobinemia" or "blue baby syndrome", and has also been associated with an increased risk of certain cancers through the formation of carcinogenic 
N-nitroso compounds [11], with spontaneous abortion [12], and with non-Hodgkin lymphoma [13]. The World Health Organization recommends a nitrate content of drinking water of less than $10 \mathrm{mg} / \mathrm{L}$ [14], and the Chinese standard for nitrate in groundwater (GB/T 14848-2017) is less than $20 \mathrm{mg} / \mathrm{L}$. The increase in nitrogen concentration in water bodies is detrimental to the stability and safety of water quality.

Complex and diversified sources of nitrogen exist in surface water, including soil nitrogen mineralization, atmospheric deposition, farmland fertilization, and sewage and industrial wastewater discharges [15]. As nitrogen pollution mainly originates from the utilization of man-made synthetic nitrogen, many studies have investigated the relationship between nitrogen and anthropogenic activities [16,17]. For example, land use changes doubled the nitrogen concentration of several watersheds in Portugal [18]. In some parts of Europe, the observed perennial value of groundwater nitrate had increased with increases in agricultural activity [19]. Nitrogen contaminants mainly came from ammonia in fertilizer and rainfall, soil nitrogen, animal feces, and livestock manure in Huixian karst wetland, China [20]. The nitrogen amount in groundwater was higher in densely populated areas, and residents faced serious health risks [21]. Different research methods have been applied in studies concerning nitrogen. By using nitrogen-stable isotope technology and a Bayesian model, it was revealed that manure, domestic sewage, and industrial wastewater discharge were the main sources of nitrogen pollution in the Weihe river [8]. A regional groundwater flow and contamination transport model of the Upper Waikato Catchment was developed and showed that $77 \%$ of surface water was sourced from groundwater, which likely made the predominant contribution to the total nitrogen load in New Zealand [22]. The export coefficient model (ECM) and the net anthropogenic nitrogen inputs (NANI) method showed that anthropogenic activities were the primary contributors of fast-growing $\mathrm{N}$ loads in the Taihu Basin [16]. Scholars developed an algorithm model for human activity intensity and established a method for converting different land use/cover types into construction land equivalents [23]. The ratio of different pollution sources to nitrogen concentrations in waters could be accurately quantified by the human activity intensity of land surface (HAILS) [24]. With the increasing population and rapid spread of industrialization and urbanization [25], land use patterns underwent tremendous changes, which significantly influenced the nitrogen in aquatic ecosystems at diverse spatiotemporal scales [26]. Many scholars have discussed the impact of excessive anthropogenic activities on the water environment or nitrogen; however, evidence regarding the relationship between large-scale time-series of the spatio-temporal changes in nitrogen and anthropogenic activities in artificial water bodies is deficient.

The Middle Route of the South-to-North Water Diversion Project (MRP) is an artificial channel with a total length of $1432 \mathrm{~km}$ (including $155 \mathrm{~km}$ of Tianjin section), which provides for the two provinces of Henan $(\mathrm{HN})$ and Hebei $(\mathrm{HB})$ and the two municipalities of Beijing (BJ) and Tianjin (TJ). At present, the impacts of this hydraulic project on groundwater and surface water in the future, including ecological safety, are controversial. Since December 2014, use of the MRP began, and the Danjiangkou Reservoir began to divert water to BJ and TJ. In previous investigations, studies only focused on the physical and chemical conditions, such as water quality, heavy metal concentrations, etc. [27-30]. Nitrogen concentration and distribution are not considered widely. In particular, studies on the relationship between the spatiotemporal heterogeneity of nitrogen and the surrounding land uses along the MRP are very limited.

To tackle these problems, the main objectives of this study were (1) to assess the spatialtemporal variations in nitrogen concentration in the MRP since 2015, (2) to demonstrate the land use cover changes in four provinces along the MRP since 2015, (3) to use the intensity of human activities to quantify the land use and analyze its relationship with nitrogen concentration, and (4) to figure out the driving factors affecting the nitrogen concentration in the MRP. This study will help us to gain insight into the heterogeneity of nitrogen and its response to anthropogenic activities after the utilization of the MRP. 


\section{Materials and Methods}

\subsection{Study Area}

The Middle Route of the South-to-North Water Diversion Project (MRP) is located between $32.68^{\circ}$ and $39.99^{\circ} \mathrm{N}$ and $111.72^{\circ}$ and $116.27^{\circ} \mathrm{E}$, with a total length of $1432 \mathrm{~km}$. The MRP originates from the Danjiangkou Reservoir, which crosses two provinces, namely HN and $\mathrm{HB}$, and arrives at BJ (the capital of China) and TJ. Water flows by gravity along the channel from the Danjiangkou Reservoir through the intake gate of the Taocha headwater. Along the middle route, the channel passes the west Tangbai River region, then crosses the watershed between the Yangtze River Basin and the Huaihe River Basin-named the Fangcheng pass-and runs across the Yellow River Basin, finally reaching BJ and TJ. This inter-basin project was planned to solve the problem of water shortage and provides clean water for production, living, industry, and agriculture for 20 large- and medium-sized cities along the route. By July in 2021, the MRP provided a total of 40 billion cubic meters of water transported northward, supplying 13.5 billion cubic meters to HN Province, 11.6 billion cubic meters to HB Province, 6.5 billion cubic meters to TJ, and 6.8 billion cubic meters to $\mathrm{BJ}$, benefiting 79 million people. The MRP protects the groundwater and improves the local ecological environment with 3 ecological function protection zones (Figure 1).

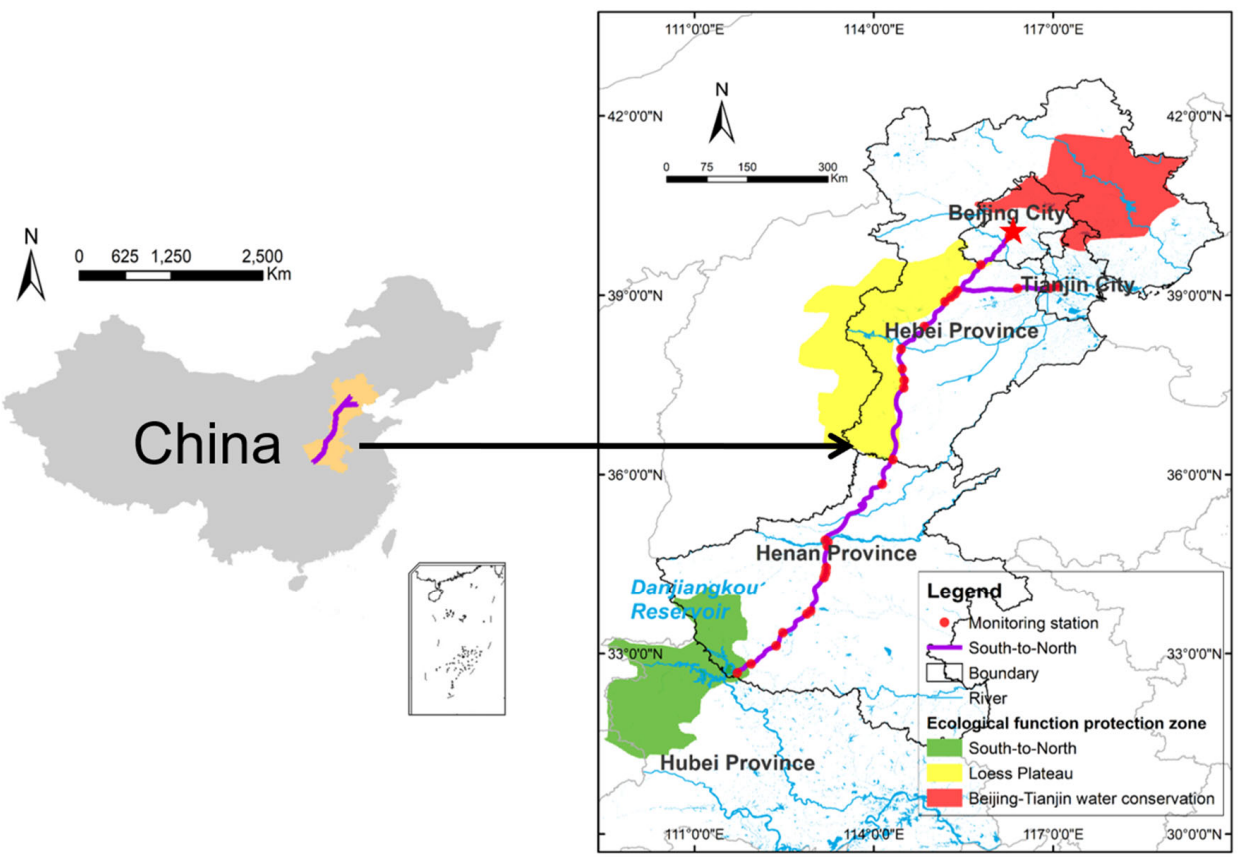

Figure 1. Sketch map of the 30 water quality monitoring stations along the Middle Route of the South-to-North Water Diversion Project.

\subsection{Sample Collection and Parameter Determination}

Thirty sampling sites were carefully selected to represent the whole MRP, covering the pivotal locations of the two provinces and the two municipalities. HN, HB, BJ, and TJ contained 16, 10, 2, and 2 sampling sites, respectively. Sixty sampling campaigns were conducted, spanning monthly variations from January 2015 to December 2019. To reduce the effects of special weather conditions, most of the samples were collected in a consistent environment under the same meteorological conditions as far as possible. Water samples were collected into 550-milliliter cleaned plastic bottles, stored at $4{ }^{\circ} \mathrm{C}$ for determination. Chlorophyll $a(\mathrm{Chl} a, \mu \mathrm{g} / \mathrm{L})$ was filtered using GF/C filters (Whatman) and measured after extraction by $90 \%$ acetone spectrophotometry in $24 \mathrm{~h}$. TN and ammonia were measured based on the standard methods for the examination of water and wastewater [31]. Water samples were digested at $120^{\circ} \mathrm{C}$ for $30 \mathrm{~min}$ to determine total nitrogen and were filtered 
through 1.2-micrometer membrane filters for later measurement of ammonia, all of which were tested using a UV spectrophotometer (UV-1780).

\subsection{Data Collection and Analysis}

\subsubsection{Data Collection}

The data files of land use were downloaded from the Resource Environment Data Cloud Platform (http:/ /www.resdc.cn/), and Landsat 5 Thematic Mapper ${ }^{\mathrm{TM}}$ (Hubei\& Hebei\&Beijing\&Tianjin) images in 2018 were obtained from the United States Geological Survey (USGS; http://glovis.usgs.gov). Then, 1-kilometer-resolution national land cover data for China were extracted from Landsat TM images using remote-sensing-based supervised classification methods (ArcGIS 10.2 software). Land use cover data in 2015 represent 2015 to 2017, and those in 2018 represent 2018 to 2019. Fertilizer consumption, urban area, and resident data for the four districts were downloaded from the Chinese yearbook website (https:/ / data.stats.gov.cn/index.htm) (Table S1).

\subsubsection{Human Activities Intensity Assessment}

Based on the perspective of the land use/cover concept, human activity intensity of land surface was defined as the degree of use, transformation, and exploitation of land surface by humans in a certain region. This degree could be reflected by land use/cover types. Obviously, human activity intensity of land surface belongs to the conceptual category of general human activity intensity, which refers to the influence of economic and social activities on a certain regional natural complex. The use, transformation, and exploitation of land surface can be seen as the main body of human activity, but not the whole. Human activity intensity of land surface could be expressed as follows [24]:

$$
\begin{gathered}
\text { HAILS }=\frac{S_{C L E}}{S} \times 100 \% \\
S_{C L E}=\sum_{i=1}^{n}\left(S L_{i} \times C I_{i}\right)
\end{gathered}
$$

where HAILS indicates human activity intensity of land surface; $S_{C L E}$ is the area of construction land equivalent; $S$ is the total land area; $S L_{i}$ is the area of land use/cover type; $C I_{i}$ is the conversion coefficient of type $i$ for construction land equivalent; and $n$ represents the number of land use/cover types.

\subsubsection{Data Calculation and Statistical Analysis}

The concentration data from $\mathrm{CAB}$ and self-determined data were processed in Excel (2019, Microsoft). Regarding space, the monitoring stations and sampling sites were divided into four units according to their districts. The spatial concentration variation was assessed using ArcGIS Esri 10.2 (Redlands, CA, USA), and the inverse distance weighting method was used to map spatial patterns [25]. Before performing statistical analysis, outliers were screened and removed to avoid errors due to abnormal factors. All the data are expressed as average and standard error (SE) values. In terms of the temporal series, the monitoring stations or sampling sites were considered as a whole, and a year was regarded as a classified unit. Comparisons of concentrations were conducted using GraphPad Prism (8.0, GraphPad). Significant differences between the mean values of parameters at the spatial and temporal scales were evaluated with the Kruskal-Wallis test and ANOVA. The Mann-Kendall test was used as an effective way to illustrate the trend of nitrogen in the channel in the time series. The non-parametric test was used to determine the rank statistics and the significance level of temporal trends from 2015 to 2019. The Mann-Kendall test was completed in MATLAB 7.0 (Natick, MA, USA), and $p<0.05$ was considered statistically significant [32]. The land use was further classified into six categories: agricultural land, forest, grassland, water body, construction, and unused land; then, the increasing ratio was 
calculated in the four districts. Human activity intensity of land surface was expressed using qualification formula and was compared between districts along the channel.

\section{Results}

\subsection{Spatial-Temporal Variation in Nitrogen}

\subsubsection{Temporal Variation}

The TN concentration ranged from 0.490 to $2.627 \mathrm{mg} / \mathrm{L}$. The mean value of TN concentration was $1.041 \pm 0.259 \mathrm{mg} / \mathrm{L}$ (summer) $>1.033 \pm 0.201 \mathrm{mg} / \mathrm{L}$ (winter) $>1.016 \pm 0.274 \mathrm{mg} / \mathrm{L}$ (spring) $>0.936 \pm 0.169 \mathrm{mg} / \mathrm{L}$ (autumn). The Kruskal-Wallis analysis exhibited that the TN value in autumn was significantly lower $(p<0.001)$ than that in summer, winter, and spring (Figure 2a). Furthermore, Figure 2b shows that TN decreased from 2015 to 2016 and then increased from 2016 to 2019. The lowest annual mean concentration of TN was $0.864 \pm 0.131 \mathrm{mg} / \mathrm{L}$ in 2016. The Kruskal-Wallis analysis showed that the difference in TN concentration among the five years was significant $(p<0.001)$, with the exception of 2016 and $2017(p<0.05)$. In addition, the Mann-Kendall test illustrated the trend of total nitrogen concentration in the time series, according to which the concentration of TN increased from 2015 to 2019 in the MRP (Figure 2c).
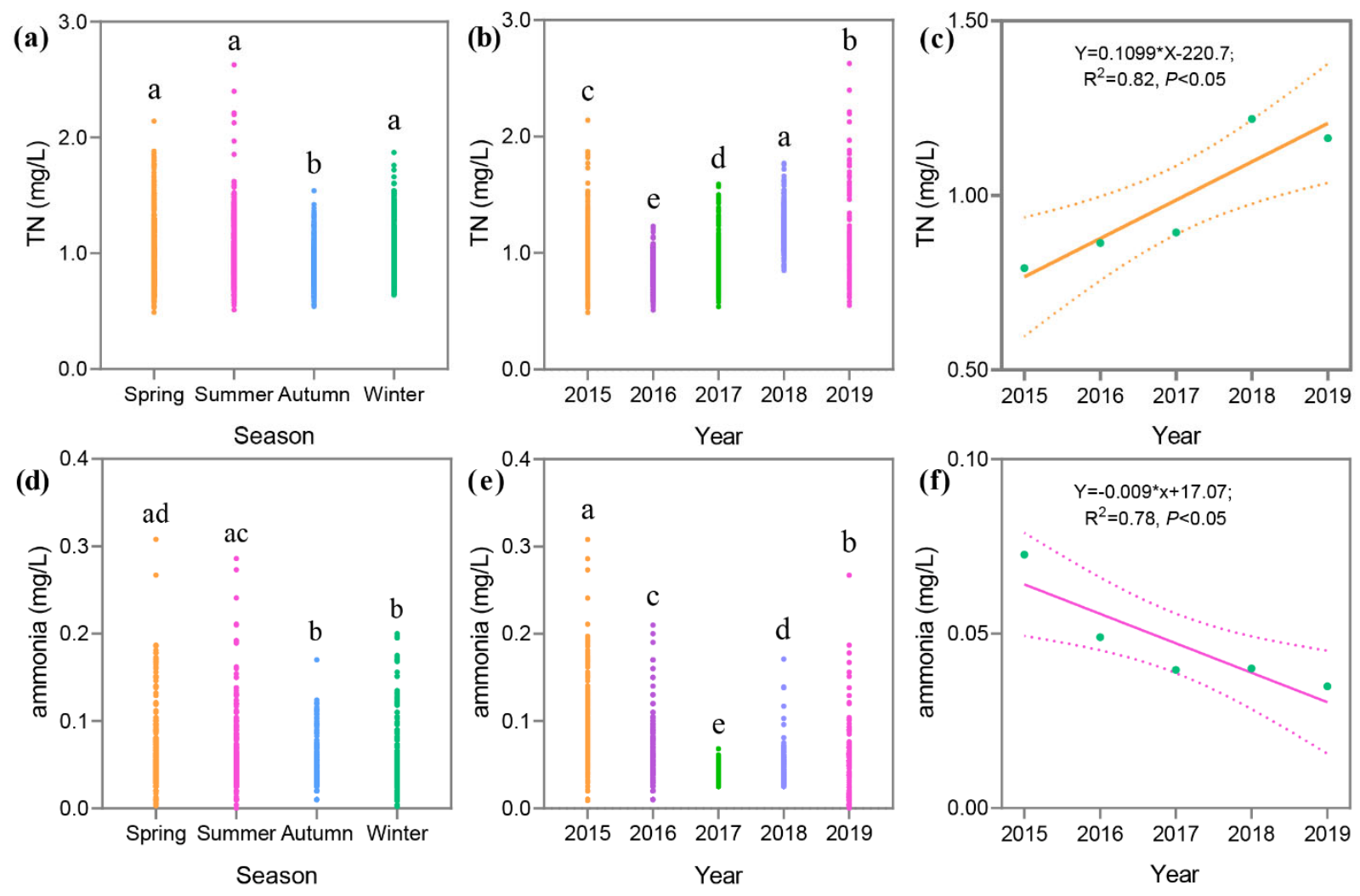

Figure 2. Temporal variation in nitrogen in the Middle Route of the South-to-North Water Diversion Project. (a) Seasonal variations in TN concentration. (b) Annual variations in TN concentration. (c) Correlations between TN and years. (d) Seasonal variations in ammonia concentration. (e) Annual variations in ammonia concentration. (f) Correlations between ammonia and years.

The concentration of ammonia varied from 0.000 to $0.308 \mathrm{mg} / \mathrm{L}$. The mean value of ammonia was $0.059 \pm 0.036 \mathrm{mg} / \mathrm{L}$ (spring) $>0.057 \pm 0.037 \mathrm{mg} / \mathrm{L}$ (summer) $>0.044 \pm 0.034 \mathrm{mg} / \mathrm{L}$ (winter) $>0.041 \pm 0.025 \mathrm{mg} / \mathrm{L}$ (autumn). The ammonia value in autumn was significantly lower $(p<0.001)$ than that in spring and summer, and there was no significant difference between autumn and winter $(p>0.05)$, nor between spring and summer $(p>0.05)$ (Figure 2d). The Mann-Kendall test showed that the ammonia concentration decreased from 2015 to 2017 and then increased from 2017 to 2019 (Figure 2e). The highest con- 
centration of ammonia was $0.073 \mathrm{mg} / \mathrm{L}$ in 2015, and the lowest was $0.035 \mathrm{mg} / \mathrm{L}$ in 2017 . The ANOVA indicated that the ammonia concentration had greatly significant differences among the five years $(p<0.001)$. In general, the concentration of ammonia decreased over time (Figure 2f).

\subsubsection{Spatial Variation}

The mean concentration of TN in all sampling sites was $1.007 \pm 0.233 \mathrm{mg} / \mathrm{L}$ (Figure 3a). The TN concentration increased from $\mathrm{HN}$ to $\mathrm{HB}$ and then decreased from $\mathrm{HB}$ to $\mathrm{BJ}$. The lowest concentration of TN was $1.000 \mathrm{mg} / \mathrm{L}$ in $\mathrm{HN}$, while the highest concentration of TN was $1.016 \pm 0.010 \mathrm{mg} / \mathrm{L}$ in $\mathrm{HB}$. The TN concentration in $\mathrm{HN}$ and $\mathrm{HB}$ exceeded $2.000 \mathrm{mg} / \mathrm{L}$. The Kruskal-Wallis analysis showed that there was no significant difference among the four districts $(p>0.05)$. To sum up, the TN concentration increased slightly along the channel over time, except in TJ (Figure 3c).
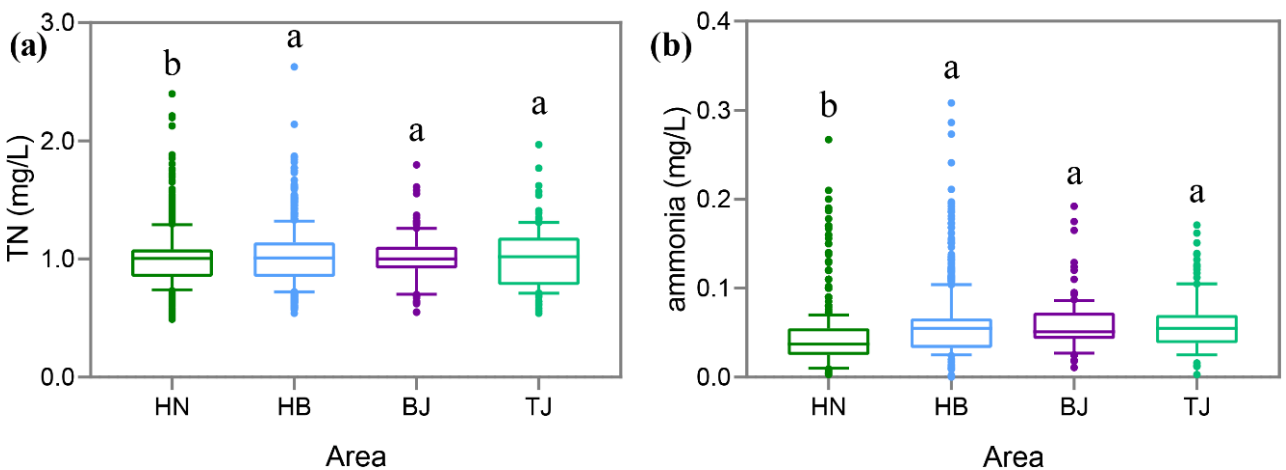

(c)

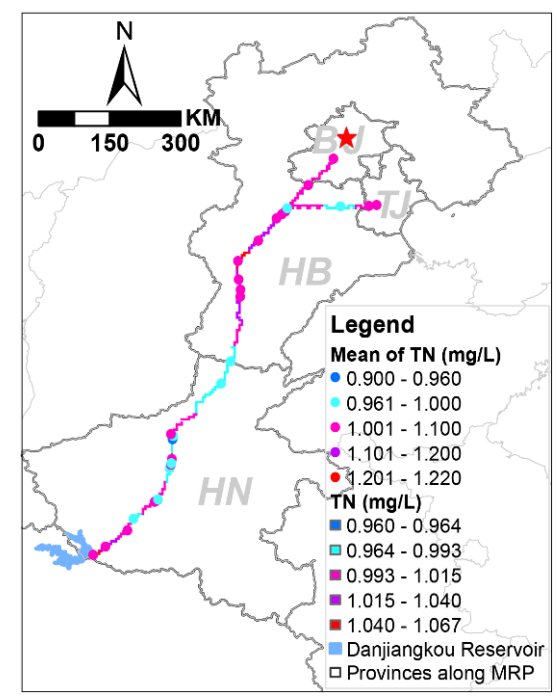

(d)

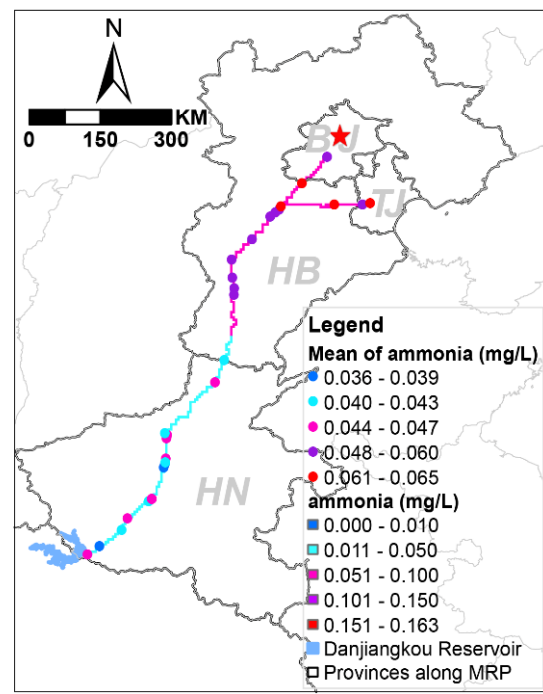

Figure 3. Spatial variation in nitrogen in the Middle Route of the South-to-North Water Diversion Project. (a) Box plot of regional variations in TN concentration. (b) Box plot of regional variations in ammonia concentration. (c) Spatial distribution of TN concentration along the channel. (d) Spatial distribution of ammonia concentration along the channel.

The annual mean concentration of ammonia was $0.050 \pm 0.013 \mathrm{mg} / \mathrm{L}$. The highest levels were found at the intersection of Xiheishan, which divides the main channel into two branches, of which one flows to BJ $(0.060 \mathrm{mg} / \mathrm{L})$ while the other flows to TJ $(0.058 \mathrm{mg} / \mathrm{L})$ (Figure $3 \mathrm{~b}$ ). The lowest concentration of ammonia was $0.037 \mathrm{mg} / \mathrm{L}$ in $\mathrm{HN}$, where the water source is located. The ANOVA substantiated that HN was significantly different compared to the other three districts $(p<0.01)$. Spatial variation in nitrogen increased simultaneously from $\mathrm{HN}$ to $\mathrm{BJ}$ and TJ along the channel, regardless of temporal variations (Figure $3 \mathrm{~d}$ ). The 
high regression fit of TN and ammonia $\left(\mathrm{r}^{2}=0.82\right.$ and 0.78 , respectively) could explain the validity and authenticity of the large proportion of data point distribution.

\subsection{Land Use Changes and Human Activity Intensity}

\subsubsection{Land Use Changes}

The area of forest, water body, and construction land use types in the four surrounding regions along the MRP increased during the entire study period; construction land in particular showed notable growth in each district. The largest average change rate of construction was in HB Province, but HN Province had the largest occupied area, covering $21,855 \mathrm{~km}^{2}$. The expansion of construction area surged yearly. Forest area also increased to a certain proportion in the four areas, and the biggest increase rate was in $\mathrm{TJ}$, accounting for $12.62 \%$, while the lowest occupation was $1.57 \%$ in HN Province. In addition, water bodies increased in $\mathrm{HN}, \mathrm{HB}$, and TJ, but not BJ. Conversely, agriculture and grassland areas reduced in size from 2015 to 2019 (Table 1). The area of agricultural land declined in all four areas, especially in $\mathrm{TJ}$ and $\mathrm{BJ}$, with change rates of $-16.17 \%$ and $-8.89 \%$, respectively. Furthermore, grassland and unused land decreased in $\mathrm{HN}$ and $\mathrm{HB}$ but increased in the $\mathrm{BJ}$ and TJ districts in the MRP (Figure 4a,b).

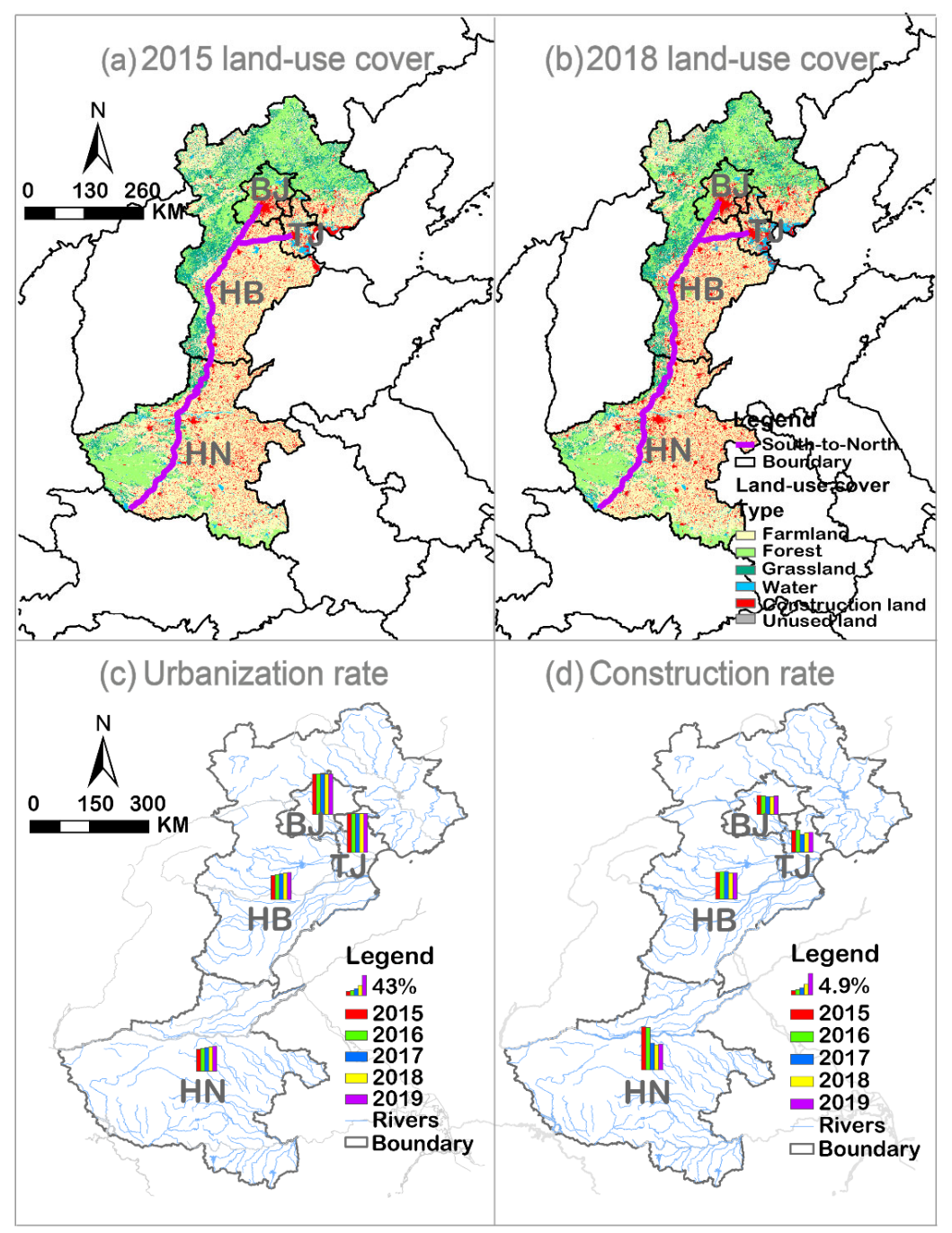

Figure 4. Land use cover changes and spatial-temporal variation in urbanization and construction rates in four regions along the Middle Route of the South-to-North Water Diversion Project in 2015 and 2018. (a) 2015-2017 land use cover. (b) 2018-2019 land use cover. (c) Urbanization rate. (d) Construction rate. 
Table 1. Spatial variation of land use in four surrounding regions along the Middle Route of the South-to-North Water Diversion Project.

\begin{tabular}{|c|c|c|c|c|c|c|c|c|c|c|c|c|}
\hline \multirow{2}{*}{ Land Use Type } & \multicolumn{2}{|c|}{ HN Area $\left(\mathrm{km}^{2}\right)$} & \multicolumn{2}{|c|}{ HB Area $\left(\mathrm{km}^{2}\right)$} & \multicolumn{2}{|c|}{ BJ Area $\left(\mathrm{km}^{2}\right)$} & \multicolumn{2}{|c|}{ TJ Area $\left(\mathrm{km}^{2}\right)$} & \multicolumn{4}{|c|}{ Annual Average Change Rate } \\
\hline & 2015 & 2018 & 2015 & 2018 & 2015 & 2018 & 2015 & 2018 & HN & НВ & BJ & $\mathrm{TJ}$ \\
\hline Agricultural land & 106,637 & 103,475 & 96,583 & 90,273 & 4410 & 3697 & 6503 & 5925 & $-2.97 \%$ & $-6.53 \%$ & $-16.17 \%$ & $-8.89 \%$ \\
\hline Forest & 26,791 & 27,212 & 36,847 & 37,891 & 7335 & 7541 & 420 & 473 & $1.57 \%$ & $2.83 \%$ & $2.81 \%$ & $12.62 \%$ \\
\hline Grassland & 9328 & 8858 & 33,411 & 32,474 & 1282 & 1299 & 192 & 314 & $-5.04 \%$ & $-2.80 \%$ & $1.33 \%$ & $63.54 \%$ \\
\hline Water body & 4076 & 4184 & 3924 & 5153 & 471 & 419 & 1749 & 1836 & $2.65 \%$ & $31.32 \%$ & $-11.04 \%$ & $4.97 \%$ \\
\hline Construction & 18,669 & 21,855 & 15,136 & 21,165 & 2881 & 3413 & 2514 & 3153 & $17.07 \%$ & $39.83 \%$ & $18.47 \%$ & $25.42 \%$ \\
\hline Unused & 61 & 31 & 1922 & 1314 & 1 & 19 & 67 & 293 & $-49.18 \%$ & $-31.63 \%$ & $1800.00 \%$ & $337.31 \%$ \\
\hline
\end{tabular}

\subsubsection{Human Activity Intensity}

Human activity intensity of land surface (HAILS) was used to quantify the pollution risk of land use changes. It could be seen that HAILS was higher in the latter period (2018-2019) than that in the period of 2015-2017, which increased by 6\% from 2015 to 2019 (Figure 5a). In addition, HAILS decreased from HN across HB to BJ, while it increased from $\mathrm{HN}$ across $\mathrm{HB}$ to TJ. The order of HAILS was TJ $>\mathrm{HN}>\mathrm{HB}>\mathrm{BJ}$ (Figure 5b), meaning that the area with the greatest HAILS was TJ. However, the biggest increase in HAILS was in $\mathrm{BJ}$, which had increased its intensity by $1.72 \%$, and the proportion of increase in HAILS was $0.98 \%, 0.02 \%$, and $0.02 \%$ in $\mathrm{TJ}, \mathrm{HB}$, and $\mathrm{HN}$, respectively.
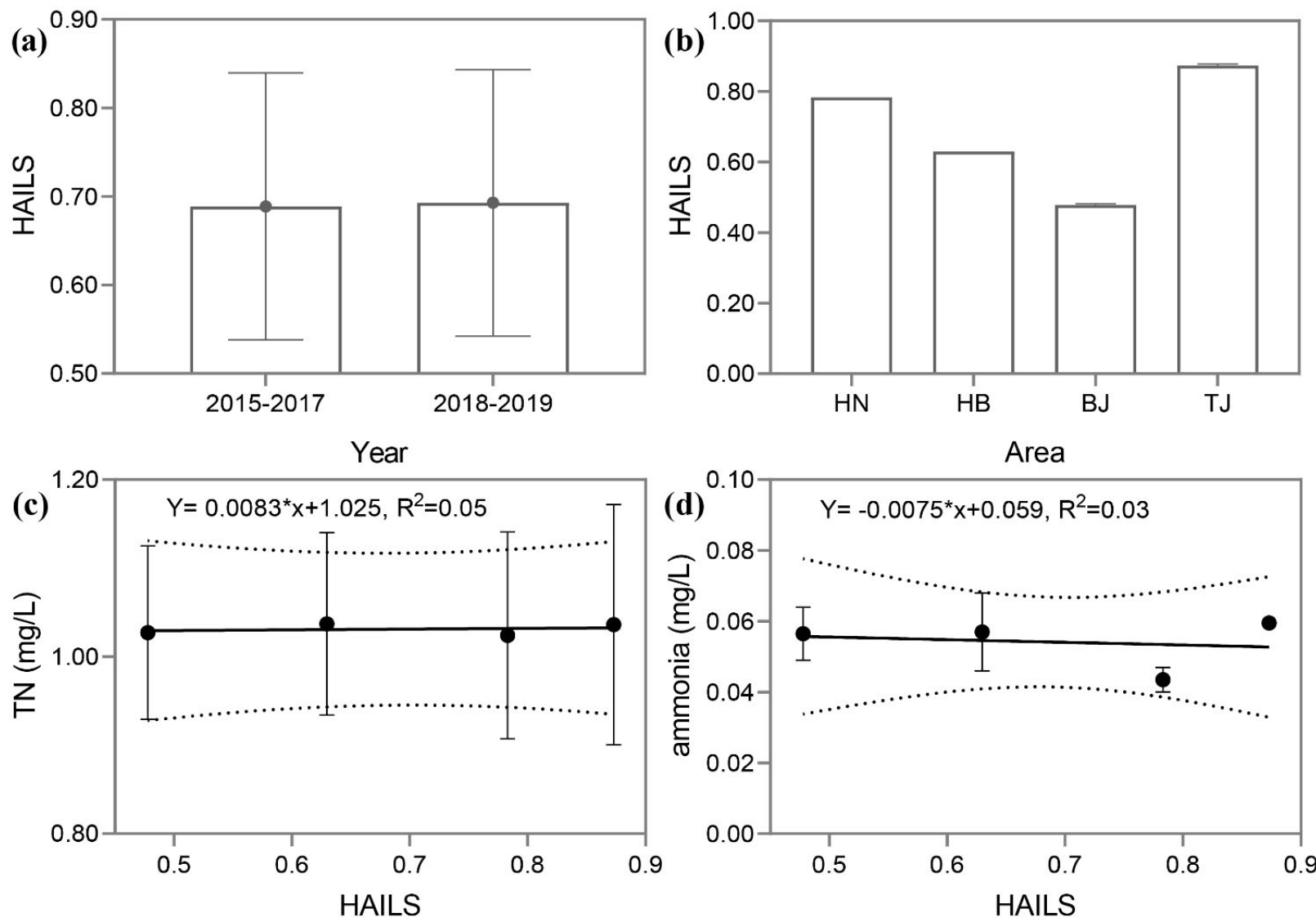

Figure 5. Human activity intensity in four regions along the Middle Route of the South-to-North Water Diversion Project. (a) Temporal variations in HAILS. (b) Spatial variations in HAILS. (c) Correlations between TN and HAILS. (d) Correlations between ammonia and HAILS. 


\subsection{Influencing Factors}

A significant linear relationship between TN, ammonia, and HAILS was found (Figure $5 c, d)(p<0.05)$. The results revealed that TN concentration was positively correlated with HAILS. However, ammonia concentration was negatively correlated with HAILS in the MRP. As HAILS rose, the concentration of nitrogen increased.

Meanwhile, it was revealed that the concentration of $\mathrm{Chl} a$ was highest in autumn. Moreover, mean concentrations of Chl $a$ changed in the following order: $4.043 \pm 3.132 \mathrm{mg} / \mathrm{L}$ (autumn) $>3.222 \pm 2.306 \mathrm{mg} / \mathrm{L}$ (summer) $>3.095 \pm 2.878 \mathrm{mg} / \mathrm{L}$ (spring) $>2.753 \pm 3.185$ $\mathrm{mg} / \mathrm{L}$ (winter). (Figure 6c). The relationship between TN, ammonia, and Chl $a$ was analyzed by linear regression (Figure $6 a, b)$. The results showed that ammonia concentration was significantly negatively correlated with $\mathrm{Chl} a(p<0.1)$, while TN concentration was not significantly correlated with $\mathrm{Chl} a$ in the MRP $(p>0.05)$ during the investigation period along the channel. In summary, as the concentration of $\mathrm{Chl} a$ increased, the concentration of ammonia decreased.
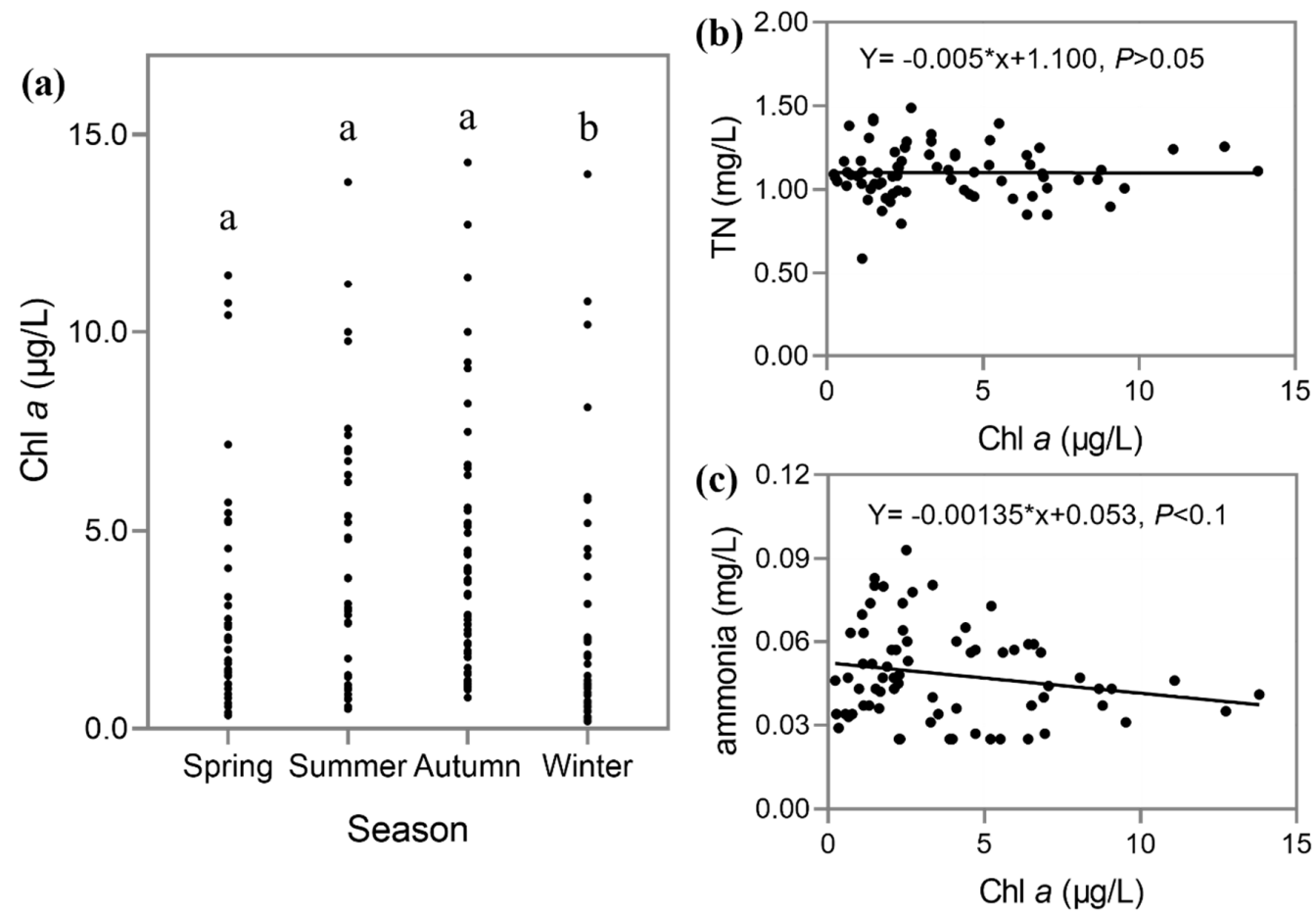

Figure 6. Regression analysis of correlation between TN, ammonia, and Chl $a$ along the Middle Route of the South-to-North Water Diversion Project. (a) Seasonal variations in Chl $a$. (b) Correlations between TN and Chl $a$. (c) Correlations between ammonia and Chl $a$.

\section{Discussion}

\subsection{Spatial Heterogeneity of $N$ in the MRP}

The MRP has been in use since December 2014. Few studies have been conducted on the $\mathrm{N}$ heterogeneity in the MRP. This study found that TN and ammonia concentrations at the end of the channel (BJ, TJ) were higher than those at the beginning $(\mathrm{HN})$, where water enters from the Danjiangkou Reservoir (Figure 3). The N concentration increased from upstream to downstream, which revealed the spatial heterogeneity of $\mathrm{N}$ distribution in the MRP. This spatial variation was also observed in other rivers; for example, the nitrogen concentration in the Lancang River increased from upstream $(0.45 \mathrm{mg} / \mathrm{L})$ to downstream $(0.87 \mathrm{mg} / \mathrm{L})$ [33], and TN and ammonia concentrations in the Yalu Tsangpo River increased from upstream $(13.99 \mu \mathrm{mol} / \mathrm{L})$ to downstream $(54.66 \mu \mathrm{mol} / \mathrm{L})$ [34], which might be caused by the spatial heterogeneity of hydraulic conditions [35].

As with natural rivers crossing different latitudes that tend to form different regions [36], the MRP, with a length of $1432 \mathrm{~km}$, spans eight degrees of latitude and four 
degrees of longitude, comprising different regions with different hydraulic conditions. In particular, Xiheishan (XS) is an intersection site where the main channel is divided into two branches-one flowing to TJ and the other flowing to BJ-and where water velocity and discharge change greatly. The discharge decreased from $46.63 \pm 14.33 \mathrm{~m}^{3} / \mathrm{s}$ (XS) to $21.29 \pm 0.11 \mathrm{~m}^{3} / \mathrm{s}$ (BJ) and $3.53 \pm 1.22 \mathrm{~m}^{3} / \mathrm{s}$ (TJ). Compared to upstream, downstream (TJ and $\mathrm{BJ}$ ) showed lower water velocity, less water discharge, and a longer retention time; these hydraulic conditions in the long-distance water diversion could become some of the most important reasons leading to the spatial heterogeneity of nitrogen [37,38]. Additionally, climatic change was another reason for $\mathrm{N}$ spatial heterogeneity due to its effects on rainfall and surface run-off $[20,39]$. A certain amount of rainfall containing $\mathrm{N}$ could directly enter the open channel; furthermore, rainfall affects the surface run-off and atmospheric nitrogen wet deposition, and both processes could bring $\mathrm{N}$ into the channel of the MRP. Indeed, nitrogen deposition (wet/dry deposition) is the main pathway for atmospheric $\mathrm{N}$ to enter water bodies, which was proven in Lake Dianchi [40], the West Yellow Sea [41], and Lake Taihu [16]. One study reported $\mathrm{NH}_{3}$ deposition exhibiting a markedly different spatial pattern, which was related to climatic change and anthropogenic activities [42]. It substantiated that the concentration of $\mathrm{N}$ deposition was much higher in agricultural and urban regions with high residential density [43]. The MRP crosses numerous agricultural and urban regions, presenting obvious $\mathrm{N}$ spatial heterogeneity.

Besides the impact of hydraulic conditions and climatic change, anthropogenic activities (e.g., land use changes, pollution discharge, fertilizer use, etc.) significantly affect aquatic environmental conditions, resulting in the spatial heterogeneity of $\mathrm{N}$ in water $[44,45]$. Non-point $\mathrm{N}$ pollution (i.e., nutrients, organic compounds, etc.) originating from anthropogenic activities in the region of the MRP should not be ignored, despite the main channel being under close-off management. There are thousands of highways and hundreds of railways over the channel; therefore, more soluble pollutants than insoluble ones in the short term and high amounts of insoluble pollutants in the long term could enter into the MRP [46,47]. Thus, the accumulative effect of pollution should be considered seriously [48]. These pollutants might increase the $\mathrm{N}$ concentration and affect water quality [49]. Highways and railways are the result of the development of transportation networks; excluding these, the spatial heterogeneity of nitrogen pollution was closely related to land use types [17], such as construction land, urbanization rate [16,50], etc. In this study, the construction land area showed a notable increase (Figure 4d), which meant the increase in urbanization rate. It could be deduced that the four regions along the MRP were undergoing urban expansion (Figure 4d). During the process of urbanization, high-intensity anthropogenic activities produced a large amount of nitrogenous domestic sewage and wastewater discharge, and part of the sewage and wastewater indirectly went into the main canal, which affected the water quality [51]. In addition, the continuous agricultural activity and utilization of nitrogen fertilizers resulted in the spatial variations in $\mathrm{N}$ concentration in the run-off, precipitation, and atmospheric nitrogen deposition $[18,44,52]$. In this study, though the agricultural area decreased significantly, the crop yields increased over time, which meant more fertilizers were used in addition to the improvement of agricultural techniques to obtain higher gross agricultural output than before. The records showed that nitrogen fertilizer consumption reached at least $2.16 \times 10^{6}$ tons/year in $\mathrm{HN}$, $1.31 \times 10^{6}$ tons/year in $\mathrm{HB}, 3.66 \times 10^{4}$ tons/year in $\mathrm{BJ}$, and $7.31 \times 10^{4}$ tons/year in $\mathrm{TJ}$, and the gross agricultural output in all areas except BJ increased over five years. Meanwhile, nutrients from fertilizers were absorbed and dissolved in run-off and transported to waters, which led to the increase in $\mathrm{N}$ concentration $[53,54]$. It can thus be concluded that the land use pattern from the upper to the lower reaches significantly influenced the spatial distribution of $\mathrm{N}$ in the MRP.

\subsection{Temporal Heterogeneity of $N$ in the MRP}

$\mathrm{N}$ temporal heterogeneity has been proven in different aquatic systems $[18,21]$. The seasonal variations in TN and ammonia in the MRP were confirmed, showing that TN 
and ammonia concentrations gradually decreased from spring to autumn, and the lowest concentrations were observed in autumn; then, they increased significantly in winter. The results were in accordance with a previous study showing that TN and ammonia reduced from spring to autumn, where the lowest concentrations of TN and ammonia were both in autumn [27]. Overall, TN increased and ammonia decreased in the past five years in the MRP.

Nitrogen is one of the most important elements for algal cells [55]; inorganic nitrogen is the preferential source for algae [56]. Ammonia can be directly absorbed by algal cells, whereas other types of nitrogen need to be converted into ammonia through various ways and then used by algal cells [55]. It was proven that absorption of ammonia by phytoplankton was greater [57]. Our results showed that there was a significant relationship between Chl $a$ and ammonia concentration $(p<0.05)$. The variations in ammonia could be attributed to algal absorption [27]. Ammonia uptake by phytoplankton in San Francisco Bay dominated DIN uptake [57], which was the nitrogen source used the earliest and that decreased the fastest. Therefore, absorption by algae was one of the reasons for ammonia declining in the MRP. Due to the significant seasonal variation in algal growth, the uptake dynamics of ammonia showed notable temporal heterogeneity.

Seasonal weather changes could also significantly affect nitrogen concentration in the MRP. For instance, ammonia exhibited considerable seasonal variation, with the maximum ammonia concentration occurring in summer, and the minimum value in autumn [58]. A study verified that seasonal variations in nitrogen were associated with the rhythm of meteorological conditions [40]. Under the influence of heavier precipitation during the wet season, atmospheric $\mathrm{N}$ finally entered the channel, and run-off produced more pollutants from different land use types [59], which enhanced the N concentration in the MRP.

Besides the above, the seasonality of anthropogenic activities (e.g., crop planting periods) resulted in nitrogen entering the water bodies. Studies have evidenced the positive correlations between nitrogen variations and agricultural land uses, especially in farming seasons [44]. TN increased along the channel over the study period (Figures 2 and 3). This might be related to the consecutive application of nitrogen fertilizers, which led to the increase in $\mathrm{N}$ emission [60]. For instance, more than $65 \%$ of the fertilization and more than $50 \%$ of livestock led to peak ammonia emissions in spring and summer [20]. Frequent agricultural activities, application of nitrogen fertilizers, and higher temperatures collectively led to an increase in ammonia concentration [58], which explains the highest ammonia concentration in spring and summer.

\section{Conclusions}

During the study period, the average value of TN and ammonia was $1.007 \pm 0.233$ and $0.050 \pm 0.013 \mathrm{mg} / \mathrm{L}$, respectively. TN and ammonia levels were higher in spring and summer than in other seasons. As the human activity intensity increased by $6 \%$, TN increased significantly from south to north; ammonia decreased significantly over the five years, which illustrated the spatio-temporal heterogeneity of $\mathrm{N}$ in the MRP. Additionally, linear regression proved that $\mathrm{Chl} a$ had a negative relationship with ammonia, which also showed seasonal variation. Besides algal absorption, hydraulic conditions, and climatic changes, the land use changes caused by human activities significantly affected the variation in nitrogen concentration in the MRP.

Due to the short time of operation of the MRP, the long-term effects of meteorological conditions still cannot be studied. Thus, long-term monitoring studies are required to provide data to validate the relationship between human activities' intensity and nitrogen heterogeneity in order to figure out the most closely related factors to control potential pollution and ensure the good quality of the MRP. For future research, we suggest setting up a new project to monitor the concentrations of $\mathrm{N}$ in draining areas around the MRP. This will help researchers to analyze $\mathrm{N}$ pollutant sources entering the main open channel. 
Supplementary Materials: The following are available online at https:/ / www.mdpi.com/article/ 10.3390/w13182517/s1, Table S1: Urban and construction information of four surrounding regions along the MRP.

Author Contributions: Investigation, Y.W. and Y.B.; conceptualization, Y.W., Y.L., and Y.B.; data curation, Y.W. and Y.L.; methodology, Y.W. and Y.L.; funding acquisition, Y.B., J.L., S.W., and Y.S.; supervision, Y.B.; writing —original draft preparation, Y.W.; writing—review and editing, Y.B. All authors have read and agreed to the published version of the manuscript.

Funding: This research was funded by the China National Critical Project for Science and Technology on Water Pollution Prevention and Control (No: 2017ZX07108-001).

Data Availability Statement: The data presented in this study are available upon request from the corresponding author.

Acknowledgments: We are thankful to Yuan Li, Jiangkui Liang, Shulei Wang and Yuming Shang for their assistance with fieldwork and analysis of water samples.

Conflicts of Interest: The authors declare no conflict of interest.

\section{References}

1. Small, G.; Sterner, R.W.; Finlay, J.C. An Ecological Network Analysis of nitrogen cycling in the Laurentian Great Lakes. Ecol. Model. 2014, 293, 150-160. [CrossRef]

2. Stüeken, E.E.; Kipp, M.; Koehler, M.C.; Buick, R. The evolution of Earth's biogeochemical nitrogen cycle. Earth-Sci. Rev. 2016, 160, 220-239. [CrossRef]

3. Thamdrup, B. New Pathways and Processes in the Global Nitrogen Cycle. Annu. Rev. Ecol. Evol. Syst. 2012, 43, 407-428. [CrossRef]

4. Kuypers, M.; Marchant, H.K.; Kartal, B. The microbial nitrogen-cycling network. Nat. Rev. Genet. 2018, 16, 263-276. [CrossRef]

5. Johnson, J.; Pannatier, E.G.; Carnicelli, S.; Cecchini, G.; Clarke, N.; Cools, N.; Hansen, K.; Meesenburg, H.; Nieminen, T.M.; Pihl-Karlsson, G.; et al. The response of soil solution chemistry in European forests to decreasing acid deposition. Glob. Chang. Biol. 2018, 24, 3603-3619. [CrossRef]

6. Paredes, I.; Ramírez, F.; Forero, M.G.; Green, A.J. Stable isotopes in helophytes reflect anthropogenic nitrogen pollution in entry streams at the Doñana World Heritage Site. Ecol. Indic. 2019, 97, 130-140. [CrossRef]

7. Wilkinson, G.M. Eutrophication of Freshwater and Coastal Ecosystems. In Encyclopedia of Sustainable Technologies; Elsevier Oxford: Oxford, UK, 2017; pp. 145-152. [CrossRef]

8. Shi, P.; Zhang, Y.; Song, J.; Li, P.; Wang, Y.; Zhang, X.; Li, Z.; Bi, Z.; Zhang, X.; Qin, Y.; et al. Response of nitrogen pollution in surface water to land use and social-economic factors in the Weihe River watershed, northwest China. Sustain. Cities Soc. 2019, 50. [CrossRef]

9. Midolo, G.; Alkemade, R.; Schipper, A.M.; Benítez-López, A.; Perring, M.P.; De Vries, W. Impacts of nitrogen addition on plant species richness and abundance: A global meta-analysis. Glob. Ecol. Biogeogr. 2018, 28, 398-413. [CrossRef]

10. Hosseini, F.S.; Malekian, A.; Choubin, B.; Rahmati, O.; Cipullo, S.; Coulon, F.; Pradhan, B. A novel machine learning-based approach for the risk assessment of nitrate groundwater contamination. Sci. Total Environ. 2018, 644, 954-962. [CrossRef] [PubMed]

11. Wedge, D.E.; Meepagala, K.M.; Magee, J.B.; Smith, S.H.; Huang, G.; Larcom, L.L. Anticarcinogenic Activity of Strawberry, Blueberry, and Raspberry Extracts to Breast and Cervical Cancer Cells. J. Med. Food 2001, 4, 49-51. [CrossRef] [PubMed]

12. Stayner, L.T.; Almberg, K.; Jones, R.M.; Graber, J.; Pedersen, M.; Turyk, M. Atrazine and nitrate in drinking water and the risk of preterm delivery and low birth weight in four Midwestern states. Environ. Res. 2017, 152, 294-303. [CrossRef] [PubMed]

13. Ward, M.H.; Brender, J.D. Drinking Water Nitrate and Human Health. Encycl. Environ. Health 2019, 173-186. [CrossRef]

14. Cotruvo, J.A. 2017 WHO guidelines for drinking water quality: First addendum to the fourth edition. J. Am. Water Work. Assoc. 2017, 109, 44-51. [CrossRef]

15. Zhang, Y.; Shi, P.; Li, F.; Wei, A.; Song, J.; Ma, J. Quantification of nitrate sources and fates in rivers in an irrigated agricultural area using environmental isotopes and a Bayesian isotope mixing model. Chemosphere 2018, 208, 493-501. [CrossRef] [PubMed]

16. Huishu, L.; Qiu, W.; Xinyu, Z.; Haw, Y.; Hongyuan, W.; Limei, Z.; Hongbin, L.; Huang, J.-C.; Tianzhi, R.; Jiaogen, Z.; et al. Effects of anthropogenic activities on long-term changes of nitrogen budget in a plain river network region: A case study in the Taihu Basin. Sci. Total Environ. 2018, 645, 1212-1220. [CrossRef] [PubMed]

17. Chen, J.; Luo, M.; Ma, R.; Zhou, H.; Zou, S.; Gan, Y. Nitrate distribution under the influence of seasonal hydrodynamic changes and human activities in Huixian karst wetland, South China. J. Contam. Hydrol. 2020, 234, 103700. [CrossRef]

18. Pacheco, F.; Fernandes, L.F.S. Environmental land use conflicts in catchments: A major cause of amplified nitrate in river water. Sci. Total Environ. 2016, 548-549, 173-188. [CrossRef] 
19. Tavakoly, A.A.; Habets, F.; Saleh, F.; Yang, Z.-L.; Bourgeois, C.; Maidment, D.R. An integrated framework to model nitrate contaminants with interactions of agriculture, groundwater, and surface water at regional scales: The STICS-EauDyssée coupled models applied over the Seine River Basin. J. Hydrol. 2019, 568, 943-958. [CrossRef]

20. Chen, S.; Cheng, M.; Guo, Z.; Xu, W.; Du, X.; Li, Y. Enhanced atmospheric ammonia (NH3) pollution in China from 2008 to 2016: Evidence from a combination of observations and emissions. Environ. Pollut. 2020, 263, 114421. [CrossRef]

21. Kim, H.-R.; Yu, S.; Oh, J.; Kim, K.-H.; Oh, Y.-Y.; Kim, H.K.; Park, S.; Yun, S.-T. Assessment of nitrogen application limits in agro-livestock farming areas using quantile regression between nitrogen loadings and groundwater nitrate levels. Agric. Ecosyst. Environ. 2019, 286, 106660. [CrossRef]

22. Rajanayaka, C.; Weir, J.; Barkle, G.; Griffiths, G.; Hadfield, J. Assessing changes in nitrogen contamination in groundwater using water aging: Waikato River, New Zealand. J. Contam. Hydrol. 2020, 234, 103686. [CrossRef]

23. Wen, Y. Preliminary discussion on the method of quantitative assessment of human activity intensity. Impact Sci. Soc. 1998, 4 , $55-60$.

24. Xu, Y.; Xu, X.; Tang, Q. Human activity intensity of land surface: Concept, methods and application in China. J. Geogr. Sci. 2016, 26, 1349-1361. [CrossRef]

25. Li, Y.; Bi, Y.; Mi, W.; Xie, S.; Ji, L. Land-use change caused by anthropogenic activities increase fluoride and arsenic pollution in groundwater and human health risk. J. Hazard. Mater. 2021, 406, 124337. [CrossRef]

26. Wilson, C.O. Land use/land cover water quality nexus: Quantifying anthropogenic influences on surface water quality. Environ. Monit. Assess. 2015, 187, 1-23. [CrossRef] [PubMed]

27. Nong, X.; Shao, D.; Xiao, Y.; Zhong, A.H. Spatio-temporal Characterization Analysis and Water Quality Assessment of the South-to-North Water Diversion Project of China. Int. J. Environ. Res. Public Health 2019, 16, 2227. [CrossRef] [PubMed]

28. Nong, X.; Shao, D.; Zhong, H.; Liang, J. Evaluation of water quality in the South-to-North Water Diversion Project of China using the water quality index (WQI) method. Water Res. 2020, 178, 115781. [CrossRef]

29. Guo, C.; Chen, Y.; Gozlan, R.E.; Liu, H.; Lu, Y.; Qu, X.; Xia, W.; Xiong, F.; Xie, S.; Wang, L. Patterns of fish communities and water quality in impounded lakes of China's south-to-north water diversion project. Sci. Total Environ. 2020, 713, 136515. [CrossRef] [PubMed]

30. Luo, Z.; Li, S.; Hou, K.; Ji, G. Spatial and seasonal bacterioplankton community dynamics in the main channel of the Middle Route of South-to-North Water Diversion Project. Res. Microbiol. 2019, 170, 24-34. [CrossRef]

31. APHA (American Public Health Association). Standard Methods for Examination of Water and Wastewater, 23rd ed.; American Water Works Association/American Public Works Association/Water Environment Federation: Washington, DC, USA, 2017.

32. Dias, J.M.; Duan, W.; He, B.; Chen, Y.; Zou, S.; Wang, Y.; Nover, D.; Chen, W.; Yang, G. Identification of long-term trends and seasonality in high-frequency water quality data from the Yangtze River basin, China. PLoS ONE 2018, 13, e0188889. [CrossRef]

33. Guo, X.; Tang, Y.; Xu, Y.; Zhang, S.; Ma, J.; Xiao, S.; Ji, D.; Yang, Z.; Liu, D. Using stable nitrogen and oxygen isotopes to identify nitrate sources in the Lancang River, upper Mekong. J. Environ. Manag. 2020, 274, 111197. [CrossRef] [PubMed]

34. Hu, M.; Wang, Y.; Du, P.; Shui, Y.; Cai, A.; Lv, C.; Bao, Y.; Li, Y.; Li, S.; Zhang, P. Tracing the sources of nitrate in the rivers and lakes of the southern areas of the Tibetan Plateau using dual nitrate isotopes. Sci. Total Environ. 2019, 658, 132-140. [CrossRef] [PubMed]

35. Hu, M.; Liu, Y.; Zhang, Y.; Dahlgren, R.; Chen, D. Coupling stable isotopes and water chemistry to assess the role of hydrological and biogeochemical processes on riverine nitrogen sources. Water Res. 2019, 150, 418-430. [CrossRef]

36. McLean, D.; Langlois, T.J.; Newman, S.J.; Holmes, T.H.; Birt, M.J.; Bornt, K.R.; Bond, T.; Collins, D.L.; Evans, S.N.; Travers, M.J.; et al. Distribution, abundance, diversity and habitat associations of fishes across a bioregion experiencing rapid coastal development. Estuarine Coast. Shelf Sci. 2016, 178, 36-47. [CrossRef]

37. Ma, P.; Zhang, L.; Mitsch, W.J. Investigating sources and transformations of nitrogen using dual stable isotopes for Lake Okeechobee restoration in Florida. Ecol. Eng. 2020, 155, 105947. [CrossRef]

38. Nazeer, S.; Khan, M.U.; Malik, R.N. Phytoplankton Spatio-temporal dynamics and its relation to nutrients and water retention time in multi-trophic system of Soan River, Pakistan. Environ. Technol. Innov. 2018, 9, 38-50. [CrossRef]

39. Wang, A.; Yang, D.; Tang, L. Spatiotemporal variation in nitrogen loads and their impacts on river water quality in the upper Yangtze River basin. J. Hydrol. 2020, 590, 125487. [CrossRef]

40. Chen, Q.; Ni, Z.; Wang, S.; Guo, Y.; Liu, S. Climate change and human activities reduced the burial efficiency of nitrogen and phosphorus in sediment from Dianchi Lake, China. J. Clean. Prod. 2020, 274, 122839. [CrossRef]

41. Zhang, J.; Liu, M.G. Observations on nutrient elements and sulphate in atmospheric wet depositions over the northwest Pacific coastal oceans-Yellow Sea. Mar. Chem. 1994, 47, 173-189. [CrossRef]

42. Liu, L.; Zhang, X.; Xu, W.; Liu, X.; Zhang, Y.; Li, Y.; Wei, J.; Lu, X.; Wang, S.; Zhang, W.; et al. Fall of oxidized while rise of reduced reactive nitrogen deposition in China. J. Clean. Prod. 2020, 272, 122875. [CrossRef]

43. Liu, X.; Duan, L.; Mo, J.; Du, E.; Shen, J.; Lu, X.; Zhang, Y.; Zhou, X.; He, C.; Zhang, F. Nitrogen deposition and its ecological impact in China: An overview. Environ. Pollut. 2011, 159, 2251-2264. [CrossRef]

44. Bu, H.; Zhang, Y.; Meng, W.; Song, X. Effects of land-use patterns on in-stream nitrogen in a highly-polluted river basin in Northeast China. Sci. Total Environ. 2016, 553, 232-242. [CrossRef]

45. Zhang, J.; Li, S.; Dong, R.; Jiang, C.; Ni, M. Influences of land use metrics at multi-spatial scales on seasonal water quality: A case study of river systems in the Three Gorges Reservoir Area, China. J. Clean. Prod. 2019, 206, 76-85. [CrossRef] 
46. Chen, R.-H.; Li, F.-P.; Zhang, H.-P.; Jiang, Y.; Mao, L.-C.; Wu, L.-L.; Chen, L. Comparative analysis of water quality and toxicity assessment methods for urban highway runoff. Sci. Total Environ. 2016, 553, 519-523. [CrossRef]

47. Crabtree, B.; Dempsey, P.; Johnson, I.; Whitehead, M. The development of a risk-based approach to managing the ecological impact of pollutants in highway runoff. Water Sci. Technol. 2008, 57, 1595-1600. [CrossRef]

48. Bakr, A.R.; Fu, G.Y.; Hedeen, D. Water quality impacts of bridge stormwater runoff from scupper drains on receiving waters: A review. Sci. Total Environ. 2020, 726, 138068. [CrossRef]

49. Johnson, R.C.; Jin, H.-S.; Carreiro, M.M.; Jack, J.D. Macroinvertebrate community structure, secondary production and trophiclevel dynamics in urban streams affected by non-point-source pollution. Freshw. Biol. 2013, 58, 843-857. [CrossRef]

50. Mainali, J.; Chang, H. Landscape and anthropogenic factors affecting spatial patterns of water quality trends in a large river basin, South Korea. J. Hydrol. 2018, 564, 26-40. [CrossRef]

51. Mello, K.; Valente, R.A.; Randhir, T.O.; dos Santos, A.C.A.; Vettorazzi, C.A. Effects of land use and land cover on water quality of low-order streams in Southeastern Brazil: Watershed versus riparian zone. Catena 2018, 167, 130-138. [CrossRef]

52. Wang, Y.; Li, Y.; Liu, X.; Liu, F.; Li, Y.; Song, L.; Li, H.; Ma, Q.; Wu, J. Relating land use patterns to stream nutrient levels in red soil agricultural catchments in subtropical central China. Environ. Sci. Pollut. Res. 2014, 21, 10481-10492. [CrossRef] [PubMed]

53. Dolman, A.M.; Rücker, J.; Pick, F.; Fastner, J.; Rohrlack, T.; Mischke, U.; Wiedner, C. Cyanobacteria and Cyanotoxins: The Influence of Nitrogen versus Phosphorus. PLoS ONE 2012, 7, e38757. [CrossRef]

54. Geng, M.M.; Wang, K.L.; Yang, N.; Li, F.; Zou, Y.A.; Chen, X.S.; Deng, Z.M.; Xie, Y.H. Evaluation and vari-ation trends analysis of water quality in response to water regime changes in a typical river-connected lake (Dongting Lake), China. Environ. Pollut. 2021, 268, 115761. [CrossRef] [PubMed]

55. Yew, G.Y.; Lee, S.Y.; Show, P.L.; Tao, Y.; Law, C.L.; Nguyen, T.T.C.; Chang, J.-S. Recent advances in algae biodiesel production: From upstream cultivation to downstream processing. Bioresour. Technol. Rep. 2019, 7, 100227. [CrossRef]

56. Kumar, A.; Bera, S. Revisiting nitrogen utilization in algae: A review on the process of regulation and assimilation. Bioresour. Technol. Rep. 2020, 12, 100584. [CrossRef]

57. Dugdale, R.C.; Wilkerson, F.P.; Hogue, V.E.; Marchi, A. The role of ammonium and nitrate in spring bloom development in San Francisco Bay. Estuar. Coast. Shelf Sci. 2007, 73, 17-29. [CrossRef]

58. Huang, X.; Song, Y.; Li, M.; Li, J.; Huo, Q.; Cai, X.; Zhu, T.; Hu, M.; Zhang, H. A high-resolution ammonia emission inventory in China. Glob. Biogeochem. Cycles 2012, 26. [CrossRef]

59. Sun, W.; Xia, C.; Xu, M.; Guo, J.; Sun, G. Application of modified water quality indices as indicators to assess the spatial and temporal trends of water quality in the Dongjiang River. Ecol. Indic. 2016, 66, 306-312. [CrossRef]

60. Zeng, J.; Yue, F.-J.; Li, S.-L.; Wang, Z.-J.; Qin, C.-Q.; Wu, Q.-X.; Xu, S. Agriculture driven nitrogen wet deposition in a karst catchment in southwest China. Agric. Ecosyst. Environ. 2020, 294, 106883. [CrossRef] 